PIOTR LISSOŃ

\title{
„REKOMUNALIZACJA” ZADAŃ W SFERZE GOSPODARKI KOMUNALNEJ
}

\section{O POJĘCIU „REKOMUNALIZACJA” ZADAŃ PUBLICZNYCH}

Efektywne wykonywanie zadań w sferze gospodarki komunalnej wymaga doboru odpowiednich form organizacyjnych i sposobów działania. Zadania mogą być wykonywane nie tylko przez podmioty komunalne. Jednostki samorządu terytorialnego podejmuja $\mathrm{w}$ wielu obszarach współpracę $\mathrm{z}$ podmiotami prywatnymi, którym powierzaja wykonywanie zadań z zakresu gospodarki komunalnej, mając do tego umocowanie w obowiązujacych przepisach prawnych, przede wszystkim $\mathrm{w}$ art. 3 ustawy o gospodarce komunalnej ${ }^{1}$.

Można jednak zaobserwować tendencję do wycofywania się przez organy samorządu terytorialnego z takiej formy współpracy w określonych obszarach usług komunalnych. Przyczyną mogą być zarówno jej niezadowalające rezultaty, jak i zmiany uwarunkowań prawnych, polegające na wprowadzeniu nowych zasad wykonywania zadań publicznych, wzmacniających rolę organów samorządu terytorialnego i podległych im struktur, a w rezultacie ograniczające rolę podmiotów prywatnych. Przykłady takich zmian były w ostatnich latach zauważalne m.in. w sferze publicznego transportu zbiorowego ${ }^{2}$ (wzmocnienie pozycji prawnej organizatora oraz operatora publicznego transportu zbiorowego), czy w sferze gospodarki odpadami (wprowadzenie obowiązku organizowania przez gminę odbioru odpadów komunalnych od właścicieli nieruchomości) ${ }^{3}$.

Tendencje do ograniczania roli podmiotów prywatnych nie tylko w sferze wykonywania zadań komunalnych, lecz także w innych sferach wykonywania zadań publicznych, na różnych szczeblach struktur państwa, dostrzegalne sa nie tylko w Polsce, ale także w innych krajach, w szczególności w Niemczech, gdzie nauka prawa poświęca im w ostatnich latach coraz większą uwagę, proponujacc nazwanie ich „rekomunalizacja”, „reetatyzacja” lub „republicyzacja” zadań publicznych ${ }^{4}$. Już samo brzmienie przytoczonych terminów wskazuje,

\footnotetext{
${ }^{1}$ Ustawa z 20 grudnia 1996 r. o gospodarce komunalnej (t.jedn.: Dz. U. 2017, poz. 827).

${ }^{2}$ Ustawa z 16 grudnia 2010 r. o publicznym transporcie zbiorowym (t.jedn.: Dz. U. 2016, poz. $1867 \mathrm{ze} \mathrm{zm}$.).

${ }^{3}$ Ustawa z 1 lipca 2011 r. o zmianie ustawy o utrzymaniu porządku i czystości w gminach (Dz. U. 2011, Nr 152, poz. 897 ze zm.).

${ }^{4}$ Zob. H. Bauer, Von der Privatisierung zur Rekommunalisierung. Einführende Problemskiz$z e$, w: H. Bauer, Ch. Büchner, L. Hajasch (Hrsg.), Rekommunalisierung öffentlicher Daseinsvorsorge, Potsdam 2012, s. 11; H. Bauer, Zukunftsthema „Rekommunalisierung“, „Die Öffentliche
} 
że zachodzące procesy można postrzegać jako przeciwieństwo dość powszechnej do niedawna - zarówno w krajach europejskich (w tym także w Polsce), jak i poza Europą (zwłaszcza w Stanach Zjednoczonych) - i występującej już od kilku dekad tendencji do „prywatyzowania” zadań publicznych, określanej również jako „odpaństwowienie” czy „odbiurokratyzowanie”. Wypracowane przez niemiecka naukę prawa ${ }^{5}$, a z czasem przyjęte także przez polską ${ }^{6}$, pojęcie „prywatyzacji zadań publicznych” jest szerokim, zbiorczym określeniem, które oznaczać ma stosowanie przez administrację prywatnoprawnych form działania, nadawanie podmiotom publicznym prywatnoprawnych form organizacyjnych (przede wszystkim formy spółek prawa handlowego), niezliczone formy i metody kooperacji administracji publicznej z podmiotami prywatnymi przy wykonywaniu zadań publicznych (określane najczęściej mianem partnerstwa publiczno-prywatnego; w skrócie: „PPP”) ${ }^{7}$, jak również towarzyszące tym procesom przekształcenia własnościowe.

Pojęcia „republicyzacja”, „reetatyzacja” czy - odnoszące się do obszaru gospodarki komunalnej - „rekomunalizacja” zadań publicznych, traktowane sa w nauce niemieckiej w sposób szeroki, obejmujący nie tylko swoiste „odwrócenie” wcześniej przeprowadzonej prywatyzacji zadań publicznych (wycofywanie się ze współpracy z podmiotami prywatnymi przy wykonywaniu zadań publicznych), ale także rozszerzenie dotychczasowego zakresu zadań publicznych przez ustanowienie zupełnie nowych zadań lub też - w przypadku możliwości wyboru

Verwaltung” 2012, nr 9, s. 329; Ch. Brüning, [Re-]Kommunalisierung von Aufgaben aus privater Hand - Maßstäbe und Grenzen, „Verwaltungsarchiv”2009, nr 100, s. 453; C. Kremer, Kommunalisierung als Element der Verwaltungsreform, „Verwaltungsarchiv” 2011, nr 102, s. 242; P. Collin, Privatisierung und Etatisierung als komplementäre Gestaltungsprozesse, „JuristenZeitung”2011, nr 6, s. 274.

${ }^{5}$ Zob. w szczególności: H. Bauer, Privatisierung von Verwaltungsaufgaben, „Veröffentlichungen der Vereinigung der Deutschen Staatsrechtslehrer” 1994, nr 54, s. 245 i n.; F. Schoch, Privatisierung von Verwaltungsaufgaben, „Deutsches Verwaltungsblatt” 1994, s. 962; R. Stober, Privatisierung öffentlicher Aufgaben, „Neue Juristische Wochenschrift”2008, nr 32, s. 2301.

${ }^{6}$ Szeroka, przekrojowa analizę form i metod prywatyzacji zadań publicznych w Polsce prezentuje monografia S. Biernata, Prywatyzacja zadań publicznych. Problematyka prawna, Warszawa-Kraków 1994; na temat pojęcia prywatyzacji zadań publicznych zob. s. 25 i n. Inspiracja do podjęcia zagadnień prywatyzacji zadań publicznych przez polską naukę prawa były bez wątpienia dokonania nauki niemieckiej, na co wskazuje treść pierwszych opracowań dotyczących tej problematyki w odniesieniu do prawa polskiego, opublikowanych jako rezultat obrad VIII Polsko-Niemieckiego Kolokwium Prawników Administratywistów, które odbyło się w 1992 r. w Krakowie; zob. artykuły S. Biernata oraz T. Skocznego pod tożsamym tytułem Die Privatisierung öffentlicher Aufgaben als Problem des Staats- und Verwaltungsrechts, opublikowane w: S. Biernat et al. (Hrsg.), Grundfragen des Verwaltungsrechts und der Privatisierung, Stuttgart-München -Hannover-Berlin-Weimar-Dresden 1994 (odpowiednio: s. 179 i 237). Z późniejszych opracowań zob. K. Bandarzewski, Prywatyzacja zadań publicznych, w: J. Zimmermann (red.), Koncepcja systemu prawa administracyjnego, Warszawa 2007, s. 331 i n.

${ }^{7}$ Zob. H. Bauer, Verwaltungskooperation - Public Private Partnerships und Public Public Partnerships - Einführende Problemskizze, w: H. Bauer, Ch. Büchner, F. Brosius-Gersdorf (Hrsg.), Verwaltungskooperation. Public Private Partnerships und Public Public Partnerships, Potsdam 2008, s. 9 i n.; na temat partnerstwa publiczno-prywatnego i jego różnych form w świetle polskich regulacji prawnych zob. B. Popowska, Partnerstwo publiczno-prywatne w świetle koncepcji „ciagu działań prawnych” i jej wptyw na ocenę umowy o PPP, w: L. Kieres (red.), Środki prawne publicznego prawa gospodarczego, Wrocław 2007, s. 145 i n. 
przez administrację pomiędzy prywatno- a publicznoprawnymi formami i metodami działania - wybór publicznoprawnych form i metod wykonywania zadań publicznych. W przypadku rozszerzania zakresu zadań czy preferowania publicznoprawnych form i metod działania za trafne uznaje się natomiast użycie określenia „publicyzacja” (i odpowiednio „komunalizacja”) zadań publicznych'.

$\mathrm{Z}$ uwagi na to, że termin „komunalizacja” posiada w polskiej terminologii prawniczej ugruntowane znaczenie, odnoszace się ściśle do przejmowania przez jednostki samorządu terytorialnego składników mienia państwowego, recypowanie go $\mathrm{w}$ znaczeniu proponowanym przez niemiecka naukę prawa, czyli odnoszacym się do rozszerzania zakresu zadań gminnych, powodowałoby, jak się wydaje, zbędne zamieszanie terminologiczne. Takiego ryzyka nie powinno raczej powodować przeniesienie do polskiej nauki prawa określenia „rekomunalizacja zadań publicznych", które posiadać ma, jak już zostało to wyjaśnione, bardzo szerokie znaczenie obejmujace różnorakie zmiany w zakresie form i sposobów wykonywania zadań gminnych, w tym także zmiany będace rezultatem przekształceń własnościowych i ukierunkowane na przeniesienie wykonywania zadań publicznych z podmiotów prywatnych na podmioty komunalne.

\section{O PRZYCZYNACH REKOMUNALIZACJI ZADAŃ PUBLICZNYCH}

Jak już wspomniano, zjawiska, które można uznać za rekomunalizację zadań publicznych, mogą dotyczyć różnych dziedzin gospodarki komunalnej i moga mieć różny charakter prawny. Jeśli chodzi o ich przyczyny, można wywodzić je z ogólnej konstatacji, która wynika z doświadczeń administracji publicznej ze współpracy z sektorem prywatnym: że funkcjonowanie podmiotów prywatnych w sferze komunalnej nie zawsze jest bardziej efektywne, tańsze czy lepsze z punktu widzenia zaspokajania potrzeb społecznych.

W niektórych przypadkach przyczyna rekomunalizacji mogą być jednoznacznie negatywne rezultaty powierzenia podmiotom prywatnym wykonywania określonych usług dla ludności. Takie przypadki odnotowywane sa w Niemczech, a jednym $\mathrm{z}$ nich jest często przytaczany $\mathrm{w}$ literaturze przykład dotyczący usług zaopatrzenia w wodę i odprowadzania ścieków w Poczdamie ${ }^{9}$. Motywy prywatyzacji, polegającej na sprzedaży w 1998 r. przez Poczdam 49\% udziałów w spółce komunalnej prywatnemu inwestorowi (z zachowaniem 51\% udziałów w rękach miasta) oraz zawarciu aż 13 obszernych umów określających zasady współpracy pomiędzy stronami, były bardzo podobne jak w większości przypadków partnerstwa publiczno-prywatnego: odciążenie budżetu miasta, uelastycznienie zasad zatrudniania pracowników, wykorzystanie know-how partnera prywatnego, zwiększenie innowacyjności przedsiębiorstwa, zmniejszenie kosztów jego działalności, polepszenie jakości i większa niezawodność świadczonych usług. Jednakże z uwagi na złożoność zawartych umów w praktyce wpływ miasta na zasady funkcjonowania spółki (i to pomimo posiadania większości udziałów) okazał się iluzoryczny. W dość krótkim czasie doszło do gwałtownego wzrostu cen (o niemal

${ }^{8}$ Zob. H. Bauer, Zukunftsthema „Rekommunalisierung“..., uwagi zawarte w przyp. 1.

${ }^{9}$ Ibidem, s. 330. 
50\%) i zarazem do uruchomienia programu drastycznej redukcji zatrudnienia w spółce. W tych okolicznościach miasto wypowiedziało zawarte umowy i odkupiło udziały od podmiotu prywatnego. Niemniej wynikajace z umów roszczenia kosztowały miasto dodatkowe 12,8 mln euro. Ponadto spółka została obciażona kosztami, które wynikały z faktu, że zakup udziałów przez prywatnego inwestora został przeprowadzony w ramach umowy forfaitingu z jednym z banków. Te koszty w tak wysokim stopniu obciążyły spółkę, że ceny usług wodociagowych i kanalizacyjnych w Poczdamie stały się jednymi z najwyższych w całych Niemczech ${ }^{10}$.

Podobne, negatywne doświadczenia z prywatyzacją zadań publicznych - a w rezultacie przypadki wycofywania się ze współpracy z podmiotami prywatnymi i powierzenia wykonywania zadań komunalnych ponownie własnym jednostkom organizacyjnym - odnotowywane sa także w innych miastach w Niemczech, m.in. w Bremie (gospodarka odpadami) ${ }^{11}$, Berlinie (usługi wodociagowe), Fryburgu (sprzątanie szkół i urzędów), Hamburgu, Bochum, Lipsku (zaopatrzenie w energię) ${ }^{12}$ czy Kilonii (komunikacja miejska) ${ }^{13}$. Co ciekawe, w wielu przypadkach wpływ na decyzję władz samorządowych o wycofaniu się ze współpracy z sektorem prywatnym miały gminne referenda, a niekiedy nawet masowe protesty mieszkańców niezadowolonych z rezultatów przeprowadzonej prywatyzacji ${ }^{14}$. Należy jednak podkreślić, że motywy rekomunalizacji zadań publicznych nie muszą wynikać wyłącznie z negatywnych doświadczeń ze współpracy gmin z podmiotami prywatnymi. W literaturze wskazuje się generalne motywy rekomunalizacji zadań publicznych, do których należy m.in. większe ukierunkowanie na interes obywateli niż na maksymalizację wyników ekonomicznych, zwiększenie wpływu organów administracji na sposób wykonywania zadań, zachowanie miejsc pracy w sektorze publicznym (zwłaszcza w słabszych gospodarczo regionach), dbałość o wysokie standardy ochrony środowiska, coraz większa efektywność struktur gminnych przy jednoczesnej dbałości o wysoka jakość świadczonych usług, dbałość o niskie ceny usług dla obywateli ${ }^{15}$.

Biorąc pod uwagę fakt, że współpraca z podmiotami prywatnymi w wielu przypadkach przynosi zakładane korzystne rezultaty, nasilającego się rekomunalizacyjnego „trendu” nie należy wcale postrzegać jako radykalnego odwrotu od współpracy administracji publicznej z sektorem prywatnym. Jak zauważa Hartmut Bauer, oba te procesy - tzn. prywatyzację i rekomunalizację zadań publicznych należy raczej postrzegać jako komplementarne strategie, wymagajace w każdym przypadku wnikliwej analizy, pozwalającej dokonać wyboru optymalnego sposobu realizowania zadań w danych warunkach ${ }^{16}$. Powyższa teza znajduje potwierdzenie zwłaszcza w polskich doświadczeniach w sektorze komunalnym, gdzie raczej rzadkością są przypadki zrywania współpracy z podmiotami prywatnymi na skutek jednoznacznie negatywnych doświadczeń. Jednocześnie współpraca jed-

10 Zob. H. Bauer, Von der Privatisierung zur Rekommunalisierung..., s. 15.

11 Zob. https://www.kreiszeitung.de/lokales/bremen/muellabfuhr-kommt-staedtische-hand-6565056. html [dostęp: 1.07.2017].

12 T. Engartner, Der Irrglaube an die Privatisierung, „Die Zeit” nr 44, 20.10.2016, s. 33.

13 Zob. H. Bauer, Von der Privatisierung zur Rekommunalisierung..., s. 19.

14 Ibidem.

15 Zob. H. Bauer, Zukunftsthema „Rekommunalisierung“..., s. 335.

${ }^{16}$ Ibidem, s. 338. 
nostek samorządu terytorialnego z podmiotami prywatnymi przy wykonywaniu zadań publicznych stale się rozwija. Jak stwierdził Michał Kania, przyjęcie nowych regulacji prawnych określających zasady zawiązywania partnerstwa publiczno-prywatnego (w postaci ustawy z 19 grudnia 2008 r. o partnerstwie publiczno-prywatnym ${ }^{17}$ oraz ustawy z 9 stycznia 2009 r. o koncesji na roboty budowlane lub usługi ${ }^{18}$ ) spotkało się z żywym zainteresowaniem w praktyce, zwłaszcza ze strony największych miast ${ }^{19}$, planujacych uruchomienie w tej formule ponad 100 przedsięwzięć. Największym z nich było powierzenie partnerowi prywatnemu obowiązków polegajacych na zaprojektowaniu, wybudowaniu, finansowaniu, zarządzaniu i utrzymaniu - w okresie 25 lat - kompletnej instalacji termicznego przekształcania odpadów komunalnych w Poznaniu. Wspomniana inwestycja to jednocześnie pierwszy w Polsce tzw. hybrydowy projekt PPP, który łączy finansowanie ze środków partnera prywatnego z dofinansowaniem ze środków Unii Europejskiej ${ }^{20}$. Z drugiej strony także w Polsce istnieją przykłady odstępowania od (niekiedy całkiem udanej) wieloletniej współpracy gmin z podmiotami prywatnymi przy wykonywaniu zadań publicznych ${ }^{21}$.

Interesującym obszarem rekomunalizacji zadań publicznych w sferze gospodarki komunalnej w Polsce, zarówno jeśli chodzi o jej przyczyny, jak i planowany sposób przeprowadzenia, jest wykonywanie usług dla ludności w sferze elektroenergetyki. Obszar ten zostanie potraktowany jako referencyjny przedmiot analiz, którym poświęcona jest dalsza część artykułu. W tej dziedzinie przygotowywane są obecnie nowe regulacje prawne, które mają zmienić zasady współpracy gmin z podmiotami prywatnymi (lub częściowo prywatnymi), jak również rozszerzyć zakres dotychczasowych zadań gminnych, zwłaszcza jeśli chodzi o zadania w zakresie oświetlania ulic i miejsc publicznych oraz zadania służące rozwojowi tzw. elektromobilności (upowszechnianiu pojazdów elektrycznych). Tym wszystkim zagadnieniom poświęcona jest dalsza część artykułu.

17 T.jedn.: Dz. U. 2015, poz. 696 ze zm.

18 T.jedn.: Dz. U. 2016, poz. 113. Ustawa z 9 stycznia 2009 r. o koncesji na roboty budowlane lub usługi utraciła moc obowiązującą na podstawie art. 71 ustawy z 21 października 2016 r. o umowie koncesji na roboty budowlane lub usługi (Dz. U. 2016, poz. 1920).

${ }_{19}$ Zob. M. Kania, Umowa o partnerstwie publiczno-prywatnym. Studium administracyjnoprawne, Katowice 2013, s. 58.

${ }^{20}$ Łączny koszt inwestycji wyniósł $832 \mathrm{mln}$ zł, w tym dofinansowanie ze środków unijnych wyniosło $330 \mathrm{mln}$ zł. Zob. Raport z doświadczeń w przygotowaniu i realizacji projektu pn. „System gospodarki odpadami komunalnymi w Poznaniu”, Platforma Partnerstwa Publiczno-Prywatnego, Listopad 2013, s. 17, a także Zielona energia $w$ formule PPP. Poznań uruchomit spalarnię odpadów, Gramwzielone.pl. Portal zielonej energii, 30.03.2017, http://gramwzielone.pl/bioenergia [dostęp: 1.07.2017].

${ }_{21}$ Takim przykładem jest choćby podpoznańska gmina Swarzędz, w której usługi komunikacji gminnej już od 1991 r. były wykonywane - na zlecenie gminy - przez prywatnego przewoźnika. Gmina w 2012 r. działalność tę powierzyła własnemu zakładowi budżetowemu. Motywy zmiany nie wynikały z negatywnych doświadczeń ze współpracy, lecz z przyczyn organizacyjnych; gmina uznała, że wykonywanie działalności w ramach własnej jednostki ułatwi przeprowadzenie dalszych zmian, niezbędnych do zintegrowania lokalnego systemu transportu z systemem transportowym stolicy Wielkopolski. Zmianę ułatwiła okoliczność, że przez cały okres współpracy, właścicielem autobusów była gmina, a nie prywatny przewoźnik. Zob. M. Juszczak, Integracja $i$ konkurencja jako sposoby kształtowania publicznego transportu zbiorowego na przyktadzie aglomeracji poznańskiej, Poznań 2013, s. 112. 


\section{AKTUALNE ZADANIA GMIN W DZIEDZINIE ELEKTROENERGETYKI \\ I ICH HISTORYCZNE UWARUNKOWANIA JAKO ASUMPT DO ROZWAŻAŃ O REKOMUNALIZACJI TYCH ZADAŃ}

W pierwszej kolejności niezbędne jest zwięzłe ukazanie aktualnego stanu zadań gminnych w dziedzinie elektroenergetyki. Zadania te zostały określone przede wszystkim w przepisach ustawy z 8 marca $1990 \mathrm{r}$. o samorządzie gminnym $^{22}$ oraz w przepisach ustawy z 10 kwietnia $1997 \mathrm{r}$. - Prawo energetyczne ${ }^{23}$. Jeśli chodzi o pierwszą z wymienionych ustaw, należy zwrócić uwagę zwłaszcza na treść art. 7 ust. 1 pkt 3, zgodnie z którym zaspokajanie zbiorowych potrzeb wspólnoty należy do zadań własnych gminy, a w szczególności zadania te obejmuja „,sprawy zaopatrzenia w energię elektryczną i cieplną oraz gaz”.

Dosłowne brzmienie tego przepisu mogłoby wskazywać, że złożony proces zaopatrywania w energię elektryczna, na który składają się techniczne procesy wytwarzania energii, a następnie jej przesyłania i dystrybucji za pomocą sieci energetycznych (zob. definicję „zaopatrzenia w energię elektryczna” $\mathrm{w}$ art. 3 pkt $8 \mathrm{PE}$ oraz definicję pojęcia „procesy energetyczne” w art. 3 pkt $7 \mathrm{PE}$ ) - realizowany jest przez gminy. Tymczasem gminy nie dysponuja ani infrastruktura przesyłowa, ani dystrybucyjna, a zdecydowana ich większość nie dysponuje infrastrukturą służącą do wytwarzania energii elektrycznej (jedynie kilkadziesiąt gmin posiada elektrociepłownie, które produkując energię cieplna, niejako ubocznie, wytwarzają także pewne ilości energii elektrycznej). Gminy nie prowadzą również sprzedaży energii dla odbiorców końcowych (a jeśli posiadają urządzenia wytwórcze, przekazują energię do ogólnokrajowego systemu energetycznego, sprzedając ją na rynku hurtowym). Rzeczywista działalność $\mathrm{w}$ zakresie zaopatrzenia $\mathrm{w}$ energię elektryczną realizowana jest przez krajowy system elektroenergetyczny, w którym kluczową rolę odgrywa wytwarzanie energii elektrycznej $\mathrm{w}$ dużych jednostkach wytwórczych (elektrowniach systemowych), następnie jej przesyłanie poprzez ogólnokrajową sieć elektroenergetyczną i wreszcie rozdzielanie do odbiorców końcowych za pomoca sieci dystrybucyjnej w 5 obszarach obsługiwanych przez spółki wchodzące w skład holdingów (grup kapitałowych), w ramach których prowadzona jest również działalność w zakresie sprzedaży energii (ENEA SA, ENERGA SA, PGE SA, TAURON Polska Energia SA oraz Innogy Polska SA). Te właśnie podmioty (4 z nich to spółki, w których Skarb Państwa jest większościowym akcjonariuszem, a mniejszościowym akcjonariuszem sa podmioty prywatne; piąta spółka jest w pełni prywatna) mają obecnie największy udział w sprzedaży energii elektrycznej do odbiorców końcowych. Trzeba jednak zaznaczyć, że wszyscy odbiorcy - zgodnie z treścia art. 4j PE - posiadaja prawo zakupu energii elektrycznej od wybranego przez siebie sprzedawcy, a na polskim rynku działa już ponad 100 mniejszych przedsiębiorstw zajmujących się jej sprzedaża.

Obecny kształt sektora elektroenergetycznego w Polsce (w którym zasadniczą rolę odgrywa 5 dużych holdingów energetycznych) jest rezultatem prze-

${ }^{22}$ T.jedn.: Dz. U. 2016, poz. 446 ze zm.

${ }^{23}$ T.jedn.: Dz. U. 2017, poz. 220 ze zm. (dalej jako: PE). 
kształceń, jakie dokonały się w nim w latach pięćdziesiątych i sześćdziesiątych XX w. Warto tymczasem podkreślić, że działalność w zakresie zaopatrywania w energię miała pierwotnie charakter lokalny, głównie miejski i dlatego została uznana za zadanie publiczne spoczywajace na gminach. Pierwsze sieci elektroenergetyczne powstały już w XIX w. ${ }^{24}$, przede wszystkim w celach oświetleniowych. $\mathrm{Na}$ ziemiach polskich pierwsze miejskie elektrownie powstały na początku XX w. i dostarczały energii elektrycznej zarówno dla potrzeb oświetlenia ulic i domów, jak i dla potrzeb zakładów komunalnych, w tym dla zasilania tramwajów (jak elektrownie w Warszawie i w Poznaniu, wybudowane w 1904 r., czy Elektrownia Łódź, wybudowana w 1907 r. $)^{25}$. Z tą sytuacją korespondowały przepisy prawne dotyczące samorządu miejskiego (ustanowione w odrodzonej Polsce w 1919 r.), które zaliczyły „zakładanie i utrzymywanie urządzeń służących do zaopatrywania miasta w światło i siłę elektryczną" do „własnego zakresu działania gminy miejskiej”"26. Kompetencje do udzielania stosownych zezwoleń na działalność w dziedzinie elektroenergetyki, zwanych „uprawnieniami rządowymi”, ustawa elektryczna z 21 marca $1922 \mathrm{r}^{27}$ przypisała organom rządowym: najpierw Ministrowi Robót Publicznych, a w późniejszym czasie Ministrowi Przemysłu i Handlu. W całym okresie międzywojennym zaopatrywanie w energię elektryczną w miastach realizowane było zasadniczo w ramach gospodarki komunalnej, choć istniały także państwowe przedsiębiorstwa energetyczne, jak również przedsiębiorstwa prywatne i przedsiębiorstwa o kapitale mieszanym (publiczno-prywatnym). W lokalnych sieciach dystrybucyjnych gminy zachowywały udziały także w przypadku ich rozbudowy z udziałem prywatnych inwestorów ${ }^{28}$. W 1938 r. czynnych było w Polsce niemal 3200 elektrowni, choć jeśli ich moc porównamy z moca współczesnych, to należy je uznać za jednostki stosunkowo małe. Przy tym sieci energetyczne nie stanowiły połączonego (ogólnokrajowego) systemu.

Gruntowne zmiany w sektorze elektroenergetycznym, które nadały mu współczesny, mocno scentralizowany kształt, nastapiły w okresie powojennym i charakteryzowała je przebudowa realizowana w kierunku połączonego, ogólnokrajowego systemu przesyłania energii, budowa nowoczesnych elektrowni o dużych mocach (rzędu kilkuset lub nawet kilku tysięcy MW) a także intensywna (powszechna) elektryfikacja kraju ${ }^{29}$. Co bardzo ważne dla prezentowanych w tym punkcie rozważań, procesy te zbiegły się z likwidacją samorządu

${ }^{24}$ Przyjmuje się, że pierwsza na świecie sieć elektroenergetyczna (o napięciu $110 \mathrm{~V}$ ) powstała na dolnym Manhattanie w Nowym Jorku w 1882 r. Już po zaledwie kilku latach elektryfikacja objęła także duże miasta europejskie, jak np. Berlin (zob. Ch. Theobald, Ch. Nill-Theobald, Grundzüge des Energiewirtschaftsrechts. Die Liberalisierung der Strom- und Gaswirtschaft, München 2013, s. 2 i n.).

${ }_{25}$ Zob. Historia polskiej energetyki, wnp.pl. Portal Gospodarczy, 18.02.2009 [dostęp: 1.07.2017].

${ }_{26}$ Art. 11 pkt 5 dekretu Naczelnika Państwa z 4 lutego 1919 r. o samorządzie miejskim (Dziennik Praw Państwa Polskiego Nr 13, poz. 140).

27 T.jedn.: Dz. U. 1935, Nr 17, poz. 98.

${ }^{28}$ Zob. L. W. Biegeleisen, Teorja i praktyka przedsiębiorstw publicznych samorzadu terytorialnego i państwa, Warszawa 1932, s. 43 i n.

${ }^{29}$ Oparta na przepisach ustawy z 28 czerwca 1950 r. o powszechnej elektryfikacji wsi i osiedli (Dz. U. 1950, Nr 28, poz. 256). 
terytorialnego na mocy ustawy z $1950 \mathrm{r} \cdot{ }^{30}$ i ustanowieniem systemu organów jednolitej władzy państwowej, to zaś miało bardzo istotne konsekwencje dla energetyki gminnej. Upaństwowienie mienia komunalnego (nie tylko elektrowni, ale także infrastruktury oświetleniowej i dystrybucyjnej), spowodowało przeniesienie elementów komunalnej infrastruktury energetycznej do większych, państwowych przedsiębiorstw.

Dokonywane w kolejnych latach dalsza przebudowa i modernizacja systemu elektroenergetycznego spowodowały, że z chwilą przywrócenia samorządu terytorialnego w 1990 r. gminy nie „odzyskały” utraconej 40 lat wcześniej infrastruktury elektroenergetycznej, gdyż ta była już częścią większych systemów o zasięgu regionalnym (terytorialnie większych nawet niż obszar ówczesnego województwa) ${ }^{31}$. Ustawodawca nie przewidział przy tym żadnych szczególnych rozwiązań, pozwalajacych np. na wydzielenie lokalnych (gminnych) odcinków sieci energetycznych ze struktur regionalnych spółek energetycznych, aby dokonać ich komunalizacji, co nie harmonizuje z treścią przepisów, które zaopatrywanie w energię elektryczną uznają za zadanie gminne. W przepisach określających zasady wyposażania nowo utworzonych w 1990 r. gmin w mienie komunalne ${ }^{32}$ nie przewidziano również możliwości przekazania gminom choćby części akcji lub udziałów w spółkach energetycznych. W rezultacie gminy ani bezpośrednio, ani nawet pośrednio nie dysponują dziś infrastrukturą niezbędną do zaopatrywania w energię elektryczną swoich mieszkańców (analogiczna sytuacja dotyczy zaopatrzenia mieszkańców w gaz, ale z uwagi na ograniczony zakres artykułu skupiony na zagadnieniach elektroenergetyki, zagadnienia te nie będą tutaj przedstawiane). Komunalizacji zostały poddane natomiast przedsiębiorstwa ciepłownicze, w tym dysponujace siecią służącą do przesyłania i dystrybucji ciepła, z uwagi na lokalny (głównie miejski) zasięg dostaw i układ przestrzenny owych sieci ${ }^{33}$.

W tej sytuacji rzeczywista rola gmin na rynku elektroenergetycznym sprowadza się dziś przede wszystkim do wykonywania zadań określonych w art. $18 \mathrm{PE}$, do których należy planowanie i organizacja zaopatrzenia w energię elektryczna (przy czym rzeczywista organizacja zaopatrzenia w energię elektryczna, jak już wyjaśniono, realizowana jest przez wspomniane wcześniej spółki energetyczne) ${ }^{34}$. Przewidziane w przepisach PE działania planistyczne zostały oparte na zasadzie swoistego podziału „ról” pomiędzy przedsiębiorstwa energetyczne, które dysponują niezbędną infrastruktura energetyczna (operatorzy systemów przesyłowych i dystrybucyjnych), a organy gmin. Operatorzy

${ }^{30}$ Ustawa z 20 marca 1950 r. o terenowych organach jednolitej władzy państwowej (Dz. U. 1950, Nr 14, poz. 130).

${ }^{31} \mathrm{Na}$ początku lat 90. XX w. funkcjonowały w Polsce 33 spółki energetyczne, które w kolejnych latach uległy konsolidacji, tworząc 5 wymienionych już wcześniej w tym artykule, dużych holdingów.

${ }^{32}$ Ustawa z 10 maja $1990 \mathrm{r}$. przepisy wprowadzające ustawę o samorządzie terytorialnym i ustawę o pracownikach samorządowych (Dz. U. 1990, Nr 32, poz. 191 ze zm.).

${ }^{33}$ Zob. B. Popowska, M. Szewczyk, Komunalizacja sektora energetycznego, „Samorząd Terytorialny” 1997, nr 6, s. 28.

${ }^{34}$ Przy czym ustawa PE nakazuje, aby treścią planów gminnych było nie tylko zaopatrzenie w energię elektryczna, ale także w ciepło oraz paliwa gazowe; z uwagi na przyjęte ramy artykułu, problematyka planowania zaopatrzenia w ciepło oraz paliwa gazowe pozostaje poza jego zakresem. 
systemów mają obowiązek sporządzenia - dla obszarów ich działania - „planów rozwoju w zakresie zaspokojenia obecnego i przyszłego zapotrzebowania na paliwa gazowe lub energię" (art. 16 ust. 1 PE). Plany powinny określać m.in. zamierzone przedsięwzięcia w zakresie modernizacji, budowy i rozbudowy sieci oraz nowych źródeł energii, przedsięwzięcia w zakresie modernizacji, budowy i rozbudowy połączeń z systemami innych państw, przedsięwzięcia racjonalizujące zużycie paliw i energii u odbiorców, przewidywany sposób finansowania tych inwestycji oraz harmonogram ich realizacji, a także przewidywane przychody niezbędne do realizacji planów (art. 16 ust. 7 PE). Operatorzy systemów przesyłowych i dystrybucyjnych mają obowiązek uzgodnienia planów (i ich aktualizacji) z Prezesem Urzędu Regulacji Energetyki.

Rola gmin jest z kolei opracowanie własnych dokumentów planistycznych; w pierwszej kolejności „założeń do planu zaopatrzenia w ciepło, energię elektryczną i paliwa gazowe". Dokument ten powinien zawierać m.in. ocenę aktualnego stanu i przewidywanych zmian zapotrzebowania na energię elektryczna, przedsięwzięcia racjonalizujące jej użytkowanie, możliwości wykorzystania istniejaccych nadwyżek i lokalnych zasobów energii, możliwości zastosowania środków poprawy efektywności energetycznej oraz zakres współpracy z innymi gminami. Zgodnie z art. 18 ust. 4 PE przedsiębiorstwa energetyczne zobowiązane są nieodpłatnie udostępniać wójtowi (burmistrzowi, prezydentowi miasta) opracowane przez siebie plany rozwoju w zakresie dotyczacym terenu danej gminy oraz propozycje niezbędne do opracowania projektu ww. założeń.

W dalszych przepisach przewidziano zasady „korelowania” planów przedsiębiorstw energetycznych z oczekiwaniami gmin co do rozwoju zaopatrzenia w energię na ich terenie. Zgodnie z art. 20 PE gminy powinny ocenić, czy plany przedsiębiorstw energetycznych zapewniają realizację przyjętych przez nie założeń. Jeśli okaże się, że nie, to gminy opracowują kolejny dokument (mający być podstawą rzeczywistej realizacji zamierzeń gminnych na lokalnym rynku energetycznym): „plan zaopatrzenia w ciepło, energię elektryczną i paliwa gazowe", który sporządza się (i uchwala) na podstawie przyjętych wcześniej założeń. Dokument ten powinien zawierać m.in. propozycje w zakresie rozwoju i modernizacji poszczególnych systemów zaopatrzenia w energię elektryczna wraz z uzasadnieniem ekonomicznym, możliwości zastosowania środków poprawy efektywności energetycznej, propozycje w zakresie wykorzystania odnawialnych źródeł energii i wysokosprawnej kogeneracji, harmonogram realizacji zadań czy przewidywane koszty realizacji proponowanych przedsięwzięć oraz źródła ich finansowania.

W praktyce gmina posiada jednak bardzo znikome możliwości oddziaływania na przedsiębiorstwo energetyczne w celu zrealizowania uchwalonego przez siebie planu. Ustawa PE reguluje tę kwestię w dwóch, dość enigmatycznie sformułowanych przepisach, art. 20 ust. 5 i 6 . Zgodnie z tymi przepisami, $\mathrm{w}$ celu realizacji planu, gmina może zawierać umowy z przedsiębiorstwami energetycznymi, a w przypadku gdy „nie jest możliwa realizacja planu na podstawie umów”, rada gminy - dla „zapewnienia zaopatrzenia” - może wskazać w drodze uchwały tę część planu, z którą prowadzone na obszarze gminy dzia- 
łania muszą być zgodne. Z przyjęciem takiej uchwały wiążą się konsekwencje określone w art. 56 ust. 1 pkt 13 PE. W świetle tego przepisu, kto realizuje działania niezgodne ze wskazana przez gminę częścia planu, podlega karze pieniężnej, która może sięgać nawet $15 \%$ przychodu osiagniętego w poprzednim roku podatkowym. Pomimo surowego brzmienia tego przepisu nie sa znane przypadki zastosowania go w praktyce, art. 20 ust. 6 PE zaś oceniany jest przez doktrynę prawa jako przepis obarczony wada, przewiduje bowiem możliwość ingerencji w sferę działań przedsiębiorstwa energetycznego za pomoca nieadekwatnych instrumentów prawnych - na podstawie uchwały rady gminy, gdy tymczasem należałoby oczekiwać, że podstawą takiej ingerencji będzie przepis powszechnie obowiąujacego prawa ${ }^{35}$.

Wydaje się, że przedstawione wyżej okoliczności i stan regulacji prawnej dość wyraźnie sygnalizują istotny problem, jaki wyłania się w sytuacji, w której gminy nie posiadajac lokalnej infrastruktury elektroenergetycznej, nie mają również możliwości wywierania realnego wpływu na działanie przedsiębiorstw, które tą infrastrukturą dysponuja, a tym samym nie mają możliwości wykonywania zadania polegającego na zaopatrywaniu w energię elektryczną. Problem ten może wywoływać pytanie, czy na obecnym etapie byłoby możliwe przeniesienie własności lub innego tytułu prawnego do dysponowania przez gminy ww. infrastruktura i uzyskanie w ten sposób przez nie możliwości samodzielnego wykonywania należących do nich zadań publicznych. Pytanie to okazuje się bardzo istotne, zwłaszcza w zakresie spraw, których dotyczy kolejny punkt.

\section{REKOMUNALIZACJA WYKONYWANIA ZADAŃ W SFERZE OŚWIETLENIA DRÓG I MIEJSC PUBLICZNYCH}

Podobnie jak w przypadku infrastruktury służącej do dystrybucji energii elektrycznej, także infrastruktura służąca do oświetlania dróg i miejsc publicznych (np. latarnie uliczne) z momentem przywrócenia w Polsce samorządu gminnego nie została przekazana gminom. Urządzenia te w większości należą obecnie do spółek energetycznych, z którymi gminy zmuszone są współpracować $\mathrm{w}$ ramach wykonywania przypisanych im zadań. Ewentualne przeniesienie tych składników do majątku gminnego uwolniłoby gminy z konieczności takiej współpracy i pozwoliło na wykonywanie ww. zadań we własnym zakresie, co można byłoby uznać za formę rekomunalizacji wykonywania zadań w omawianym obszarze.

Przepisy PE nakładaja na gminy szereg (kosztownych) zadań związanych z oświetlaniem dróg i miejsc publicznych na terenie gminy. Do zadań tych należy, po pierwsze, planowanie oświetlenia znajdujacego się na terenie gminy (art. 18 ust. 1 pkt 2 i $3 \mathrm{PE}$ ), a przepis ustawy szczegółowo określa kategorie dróg, których oświetlenie ma być przedmiotem gminnych planów. Po drugie,

${ }^{35}$ Zob. M. Czarnecka, T. Ogłódek, Prawo energetyczne. Komentarz, Warszawa 2010, s. 370; J. Baehr, E. Stawicki, J. Antczak, Prawo energetyczne. Komentarz, Kraków 2003, s. 176. 
art. 18 ust. 1 pkt 3 PE nakłada na gminy obowiązek finansowania oświetlenia wskazanych w tym przepisie miejsc i dróg publicznych, przy czym termin „finansowanie oświetlenia" oznacza zarówno finansowanie kosztów energii elektrycznej pobranej przez punkty świetlne, jak i (całkiem sporych) kosztów ich budowy i utrzymania (o czym stanowi art. 3 pkt $22 \mathrm{PE}$ ).

Wykonywanie tych zadań przebiega w bardzo niekorzystnych dla gmin warunkach monopolistycznego rynku: na danym terenie istnieje zwykle tylko jedno przedsiębiorstwo energetyczne posiadające infrastrukturę oświetleniową (tzw. punkty świetle), gminy zaś nie mają żadnego wpływu ani na koszty energii elektrycznej pobieranej przez punkty świetlne, ani na koszty związane z budową i utrzymaniem tych punktów, w szczególności nie posiadają żadnych instrumentów prawnych, za pomocą których mogłyby skłonić przedsiębiorstwo energetyczne do obniżenia ww. kosztów, np. przez zastosowanie energooszczędnych źródeł światła bądź powierzenie konserwacji urządzeń tańszym podwykonawcom. Przepisy ustawy PE nie przewidują również żadnych instrumentów nadzoru lub regulacji tych stawek ze strony innych organów, w szczególności Prezesa URE. Nie dziwi zatem fakt, że proponowane przez przedsiębiorstwa energetyczne stawki opłat często są oceniane przez gminy jako wygórowane. Problem ten nasilił się, gdy w strukturach holdingów energetycznych wyodrębniono spółki powołane ściśle do zarządzania infrastrukturą oświetleniowa, a wraz z ich powołaniem w wielu przypadkach znacznie podniesiono wysokość opłat za świadczone usługi. Dlatego w przypadku miejsc, które wcześniej nie były oświetlone (np. nowe drogi czy osiedla), gminy instaluja własne urządzenia, uniezależniając się od przedsiębiorstw energetycznych. W wielu przypadkach bywało jednak i tak, że gminy zgadzały się na nieodpłatne przekazywanie wybudowanych przez siebie urządzeń oświetleniowych spółkom energetycznym, które - nadużywając posiadanej pozycji rynkowej - stawiały taki wymóg jako warunek przyłączenia tych urządzeń do sieci elektroenergetycznej.

$\mathrm{Na}$ przestrzeni ostatnich lat gminy podejmowały inicjatywy przeciwdziałania istniejącym niedogodnościom. Dla przykładu w 2011 r. władze gmin z terenu województwa kujawsko-pomorskiego zawiąały porozumienie międzygminne (Porozumienie Ciechocińskie) „w celu obrony reprezentowanych przez nie społeczności lokalnych przed monopolistycznymi praktykami” jednej ze spółek energetycznych ${ }^{36}$. Zwrócono się wówczas do Sejmu o zainicjowanie zmian legislacyjnych mających na celu umożliwienie samorządom organizowania przetargów na dostawę energii elektrycznej dla celów oświetleniowych oraz konserwacji punktów świetlnych stanowiących własność spółek energetycznych. Wskazano także na potrzebę wprowadzenia takich zmian legislacyjnych, które stworzyłyby możliwość rekomunalizacji majątku oświetleniowego, powstałego ze środków samorządów, względnie stworzyłyby możliwość jego odkupienia przez zainteresowane samorządy ${ }^{37}$.

${ }^{36}$ Zob. T. Ciechoński, Energa kontra samorzady, czyli spięcie pod latarnia, „Gazeta Wyborcza” (Toruń), 22.02.2011; http://torun.wyborcza.pl/torun/1,35576,9143097,Energa_kontra_samorzady_czyli_spiecie_pod_latarnia.html?disableRedirects=true [dostęp: 1.07.2017].

${ }_{37}$ Tekst dokumentu dostępny jest na stronach internetowych miasta Kowal: http://www.kowal.eu [dostęp: 1.07.2017]. 
Inicjatywa ta nie spowodowała jednak podjęcia oczekiwanych przez gminy prac legislacyjnych. Takie prace zostały podjęte dopiero przez Sejm VIII kadencji, na podstawie propozycji wypracowanych przez Zwiąek Miast Polskich ${ }^{38}$. Przygotowany przez grupę posłów, niezbyt obszerny projekt ustawy o zmianie ustawy - Prawo energetyczne (wersja z 21 września 2016 r.) przewiduje trzy rozwiązania. Po pierwsze, przedsiębiorstwo energetyczne ma „umożliwić gminie nieodpłatnie wykorzystywanie elementów sieci elektroenergetycznej, będących własnością tego przedsiębiorstwa, do mocowania punktów świetlnych oraz dostęp do nich w zakresie niezbędnym w celu ich utrzymania", owe zaś „punkty świetlne” mają stanowić własność „podmiotu, na koszt którego zostały zrealizowane". Po drugie, przedsiębiorstwo energetyczne w terminie 36 miesięcy od dnia wejścia w życie ustawy nowelizującej na wniosek gminy, na terenie której zlokalizowane są punkty świetlne, ma przenieść na rzecz gminy własność punktów świetlnych, które zostały uprzednio nieodpłatnie przekazane przez gminę na rzecz przedsiębiorstwa energetycznego za zwrotem różnicy pomiędzy wartością punktów świetlnych z dnia ich przejęcia przez przedsiębiorstwo, a wartością tych punktów na dzień przekazywania gminie (art. 2 ust. 1 projektu). Po trzecie wreszcie, punkty świetlne niewymienione w poprzednim przepisie, stanowiące własność przedsiębiorstwa energetycznego, mają zostać przeniesione ( $\mathrm{w}$ ww. terminie) na rzecz gminy, na terenie której są lokalizowane za zapłatą rzeczywistej wartości tych punktów ustaloną na dzień przeniesienia ich własności na rzecz gminy.

Wydaje się, że wdrożenie przedstawionych propozycji legislacyjnych może wywoływać poważne wątpliwości prawne; przedsiębiorstwa energetyczne, które byłyby adresatami przepisów projektowanej ustawy to niejednokrotnie spółki notowane na giełdzie, a pozbawienie ich części posiadanego mienia (będace $\mathrm{w}$ istocie rodzajem wywłaszczenia), może rodzić wątpliwości na gruncie konstytucyjnych gwarancji prawa własności. Niemniej wydaje się słuszna sama idea wyposażenia gmin $\mathrm{w}$ mienie niezbędne do wykonywania nałożonych na nie zadań publicznych jednocześnie generujacych znaczne koszty, do których ponoszenia gminy zostały ustawowo zobowiązane.

\section{NOWE ZADANIA GMIN W ZAKRESIE ROZWOJU ELEKTROMOBILNOŚCI}

Projekt ustawy o elektromobilności i paliwach alternatywnych ${ }^{39}$ nakłada na gminy zupełnie nowe, nieistniejące wcześniej zadania publiczne. Zadania te maja służyć wspieraniu rozwoju infrastruktury niezbędnej do zaopatry-

${ }^{38}$ Zob. T. Żółciak, Gminna wojna o lampy. Branżę energetyczna czeka rewolucja, Gazeta Prawna.pl, 23.05.2016; http://serwisy.gazetaprawna.pl/energetyka/artykuly/946015,oswietlenie-uliczne-lampy-gminy-zaklady-energetyczne.html [dostęp: 1.07.2017].

${ }^{39}$ Projekt z 26 kwietnia 2017 r. opracowany przez Ministerstwo Energii. 
wania pojazdów samochodowych w energię elektryczna, a także w gaz ziemny w postaci $\mathrm{CNG}^{40}$ bądź $\mathrm{LNG}^{41}$. Z uwagi na przyjęte ramy artykułu kwestie infrastruktury gazowej zostaną w dalszych rozważaniach pominięte.

W projekcie ustawy przewidziano szereg instrumentów, które maja służyć budowie punktów ładowania pojazdów elektrycznych i przyczyniać się do oczekiwanego przez rząd rozwoju rynku takich pojazdów ${ }^{42}$. W pierwszej kolejności trzeba zwrócić uwagę na działania planistyczne. Zastosowano tu podobną zasadę jak w przypadku scharakteryzowanego wcześniej planowania zaopatrzenia w energię na terenie gminy, polegająca na podziale „ról” pomiędzy przedsiębiorstwa energetyczne (operatorów systemów dystrybucyjnych) a organy gmin. Zgodnie $\mathrm{z}$ art. 3 ust. 1 projektu na operatora systemu dystrybucyjnego elektroenergetycznego nałożono obowiązek opracowania „programu budowy ogólnodostępnych punktów ładowania oraz przedsięwzięć niezbędnych do przyłączenia tych punktów do sieci, w szczególności modernizacji, rozbudowy albo budowy sieci”. Operator ma obowiązek sporządzić program tylko w odniesieniu do większych gmin położonych na obszarze swego działania, które spełniaja łącznie trzy kryteria: liczba mieszkańców wynosi co najmniej 100 tys., w gminie jest zarejestrowanych co najmniej 60 tys. pojazdów samochodowych, na 1000 mieszkańców gminy przypada zaś co najmniej 400 pojazdów samochodowych (to trzecie kryterium będzie miało znaczenie w przypadku gmin przekraczających 100 tys. mieszkańców).

Program powinien zawierać m.in. liczbę planowanych ogólnodostępnych punktów ładowania, ich parametry techniczne oraz proponowane lokalizacje, określać przewidywane zapotrzebowanie na energię elektryczną w transporcie drogowym na terenie gminy, a także liczbę i parametry techniczne już istniejących na jej terenie ogólnodostępnych punktów ładowania. Natomiast zadaniem gmin jest sporządzenie szczegółowego ,planu rozmieszczenia ogólnodostępnych punktów ładowania wraz z oczekiwanym terminem ich budowy". Niestety, projekt ustawy nie reguluje kwestii rozwiązywania ewentualnych rozbieżności pomiędzy planami gmin a programami opracowanymi przez przedsiębiorstwa energetyczne.

Poza zadaniami w zakresie sporządzania ww. planu projekt przewiduje także szereg innych zadań gminnych w sferze elektromobilności, do których należy m.in. wyłanianie (w drodze konkursu) operatora infrastruktury dla ogólnodostępnych punktów ładowania wskazanych w planie, ustanawianie „stref zeroemisyjnego transportu” (do których ogranicza się dostęp innych pojazdów niż pojazdy elektryczne) czy obowiązek zapewnienia odpowiedniego udziału pojazdów elektrycznych we flocie pojazdów posiadanych przez gminę (ten obowiązek dotyczy także powiatów i samorządów województw).

40 Sprężony gaz ziemny (ang. compressed natural gas - CNG).

41 Skroplony gaz ziemny (ang. liquefied natural gas - LNG).

${ }^{42}$ Zob. Plan rozwoju elektromobilności w Polsce, Ministerstwo Energii, Warszawa 2016, s. 18. 


\section{WNIOSKI}

Określenie „rekomunalizacja zadań publicznych” dobrze odpowiada procesom, jakie zachodzą obecnie w wielu obszarach gospodarki komunalnej, a które polegają na wycofywaniu się przez jednostki samorządu terytorialnego ze współpracy z podmiotami prywatnymi przy wykonywaniu zadań publicznych, preferowaniu przez organy administracji publicznoprawnych form i metod działania, czy wreszcie na stałym rozszerzaniu przez ustawodawcę zakresu zadań publicznych należących do jednostek samorządu terytorialnego.

Jak wynika z przedstawionych $\mathrm{w}$ artykule przykładów, procesy te moga mieć różne przyczyny i różny kształt prawny w poszczególnych dziedzinach zadań. Potraktowany w artykule jako referencyjny obszar zadań gminnych w sferze elektroenergetyki ukazał specyficzne motywy i sposoby jej przeprowadzenia. Do motywów tych należy przede wszystkim splot dwóch okoliczności: z jednej strony brak po stronie gmin odpowiedniej infrastruktury elektroenergetycznej, niezbędnej do wykonywania postawionych przed nimi zadań, z drugiej zaś - brak odpowiednich instrumentów prawnych, za pomoca których gminy mogłyby oddziaływać na przedsiębiorstwa energetyczne, gdyż to one dysponuja odpowiednia infrastruktura, a gminy zmuszone sa z nimi w warunkach monopolistycznie ukształtowanego rynku - współpracować przy realizowaniu swych ustawowych zadań.

Ostatnimi czasy rozdźwięk pomiędzy przypisanymi gminom zadaniami a brakiem możliwości ich efektywnej realizacji stał się szczególnie mocno odczuwalny w sferze oświetlenia ulic i miejsc publicznych, co uruchomiło procesy legislacyjne, które mogą doprowadzić do ukształtowania się nowych warunków, w których zadania te będą wykonywane, a mianowicie do umożliwienia gminom wykonywania tych zadań we własnym zakresie, dzięki wykorzystaniu własnej infrastruktury technicznej. Wydaje się, że w perspektywie najbliższych lat należy liczyć się z dalszym rozwojem gminnej działalności w zakresie energetyki, a katalizatorem tej tendencji moga być przedstawione w artykule inicjatywy legislacyjne związane z rozwojem sektora pojazdów elektrycznych, czego konsekwencją będzie także zwiększenie lokalnych potrzeb w zakresie zaopatrzenia $\mathrm{w}$ energię.

Natomiast należy się zgodzić z prezentowaną przez H. Bauera (przytoczoną w pkt II artykułu) generalną teza, że nasilającego się trendu w zakresie rekomunalizacji zadań publicznych nie trzeba wcale postrzegać jako radykalnego odwrotu od współpracy administracji publicznej z sektorem prywatnym. Oba te zjawiska należy raczej postrzegać jako komplementarne strategie, pozwalające dokonać wyboru optymalnego sposobu realizowania zadań publicznych w danych warunkach.

dr Piotr Lissoń

Uniwersytet im. Adama Mickiewicza w Poznaniu piotr.lisson@amu.edu.pl 


\section{THE 'REMUNICIPALISATION’ OF TASKS IN THE SPHERE OF MUNICIPAL ECONOMY}

\section{Sum mary}

One of the tendencies recently observed in the sphere of municipal economy is a gradual resignation by units of territorial self-government from co-operation with private entities on joint projects involving realisation of public tasks. Likewise, where there is an opportunity to choose between private and private-public forms of activity, the tendency is to opt for a publicprivate form and method to complete the task. A constant increase in the scope of public tasks vested in territorial self-governing units can also be noted. Such tendencies are observed not only in Poland but in other countries as well, notably in Germany where legal scholars have lately devoted a considerable amount of time to studying the phenomenon which they call different names including remunicipalisation and republicisation (meaning returning public tasks to public bodies) of public tasks. It seems that similar names can be given to such research undertaken in Poland. Examples from such remunicipalisation of public tasks in the field of electrical-engineering have been given. 
